\title{
HUBUNGAN ANTARA MINAT DAN SIKAP SISWA TERHADAP KEMAMPUAN UNDAK-USUK BASA SUNDA SISWA KELAS X 9 SMAN 9 BANDUNG
}

\author{
Evi Nurmayatini \\ SMA Rimba Madya Bogor \\ email: evinurmayatini@yahoo.com
}

\begin{abstract}
Abstrak
Penelitian ini dilatarbelakangi oleh rendahnya kemampuan undak-usuk basa Sunda siswa dalam pelajaran bahasa Sunda. Berdasarkan permasalahan dan tujuannya, dideskripsikan tentang korelasi minat belajar dan sikap berbahasa terhadap kemampuan undak-usuk basa Sunda siswa kelas X 9 SMAN 9 Bandung. Metode yang digunakan adalah metode deskripsi analitik korelasional. Teknik yang digunakan adalah teknik angket dan tes. Penelitian ini bertujuan untuk mengetahui seberapa besar pengaruh minat dan sikep terhadap kamampuan undak-usuk basa Sunda siswa. Besarnya korelasi antara variabel minat dan sikep terhadap kamampuan undak-usuk basa Sunda yang dihitung menggunakan koefisien korelasi adalah 0.132. Dengan demikian bisa diinterpretasikan hubungan antara variabel minat dan sikap terhadap kemampuan undak-usuk basa Sunda rendah. Koefisien determinasi variabel minat dan sikap terhadap kemampuan undak-usuk basa Sunda adalah 2.8\%. Artinya, kemampuan undak-usuk basa Sunda dipengaruhi oleh variabel minat dan variabel sikap sebesar $2.8 \%$ sedangkan sisanya dipengaruhi oleh faktor lain.
\end{abstract}

Kata Kunci: Minat, Sikap dan Kemampuan

\section{THE CORRELATION BETWEEN STUDENTS' INTEREST AND ATTITUDE A ND THEIR ABILITY OF USING SUNDANESE SPEECH LEVELS OF GRADE X STUDENTS OF SMAN 9 BANDUNG}

\begin{abstract}
The lack of students' ability of using Sundanese speech levels in learning Sundanese motivated this study. The goal was to describe the correlation of interests and attitudes and the ability to use Sundanese speech levels of Grade X students of SMAN 9 Bandung. The method used was correlational-analytical, using questionnaires and tests. The reseach aims to determine the extent to which interests and attitudes influence students' ability of using speech levels. The amount of correlation between interest and attitude variables and students' ability was calculated using the correlation coefficient of 0.132. It was found that the correlation between interest and attitude variables and ability was low. The coefficient of interests and attitudes and students' ability was 2.8\%. It means that the influence of interests and attitudes to students' ability of using speech levels was about $2.8 \%$, while the rest was influenced by many other factors
\end{abstract}

Keywords: interest, attitude, and ability 


\section{PENDAHULUAN}

Dilihat dari keadaan dan situasi undakusuk basa Sunda jaman sekarang utamanya di kalangan anak-anak remaja tingkat SMA, yang kehidupannya terpengaruh oleh perkembangan jaman, yang biasanya menjadi masalah adalah kurangnya minat dan sikap berbahasa terhadap pelajaran Bahasa Sunda di sekolah. Minat dan sikap berbahasa mempunyai peranan menumbuhkan kesadaran diri siswa supaya belajar menggunakan bahasa yang baik.

Dalam proses belajar, minat dan sikap termasuk faktor internal yang ada di dalam diri siswa. Setiap siswa pasti mempunyai taraf minat dan sikap yang berbeda. Minat merupakan alat motivasi yang utama untuk membangun keinginan atau kegairahan belajar siswa, sedangkan sikap merupakan gambaran dari minat yang dimiliki.

Dalam berinteraksi beberapa siswa SMAN 9 Bandung lebih memilih untuk menggunakan bahasa Indonesia. Karena bahasa Indonesia lebih mudah daripada bahasa Sunda, walaupun keturunan orang Sunda asli, tapi bahasa ibu dan bahasa sehari-hari di rumahnya menggunakan bahasa Indonesia.

Sebagaimana yang telah dijelaskan di atas ada beberapa faktor yang bisa mempengaruhi kemampuan undak-usuk basa Sunda siswa yaitu minat dan sikap. Minat merupakan support atau motivasi untuk melakukan kagiatan belajar. Dengan adanya partisipasi siswa maka siswa bisa terlibat langsung dalam kegiatan belajar dan akan memperhatikan guru sampai timbul rasa ingin tahu dan ingin belajar dengan sungguh-sungguh. Dalam Kamus Besar Bahasa Indonesia (1994:656) minat yaitu kecenderungan hati terhadap suatu hal; gairah; keinginan. Jarsild dan Tasch (Nurkancana dan Sumartana 1983:224) menjelaskan bahwa minat atau interst adalah segala hal menyangkut aktivitas yang dipilih secara bebas oleh satu individu.

Sikap yang dimiliki oleh satu individu akan menentukan prilakunya. Dahlan (dalam Haerudin, 1998:11) mengungkapkan bahwa sikap merupakan kesiapan mental atau moral yang terorganisasikan melewati pengalaman dan pengaruh terhadap tingkah laku individu dalam merespon objek tertentu. Trandis (dalam Suwito, 1974:2-4) berpendapat bahwa sikap pada hakekatnya adalah "kesiapan beraksi" terhadap sesuatu keadaan. Kesiapan demikian mungkin merujuk kepada "sikap mental" dan mungkin merujuk kepada "sikap perilaku".

Sikap yang dimaksud dalam penelitian ini adalah sikap berbahasa. Sikap bahasa (language attitude) yaitu peristiwa kejiwaan dan merupakan bagian dari sikap (attitude) pada umumnya. Menurut Fishman (Haerudin, 1998:16) Sikap berbahasa merupakan reaksi penelitian terhadap bahasa tertentu. Pendapat di atas menyatakan bahwa sikap berbahasa merupakan reaksi seseorang (pemakai bahasa) terhadap bahasanya maupun bahasa orang lain. Sikap bahasa timbul bila seseorang itu sebagai masyarakat yang dwibahasawan atau multibahasawan. Menurut Pateda (Haerudin, 1998:16) Sikap berbahasa itu dapat dikelompokkan menjadi dua bagian, yaitu sikap terhadap bahasa dan sikap berbahasa. Sikap terhadap bahasa penekanannya tertuju pada tanggung jawab dan penghargaannya terhadap bahasa, sedangkan sikap berbahasa ditekankan pada kesadaran diri dalam menggunakan bahasa secara tertib

Dalam penelitian ini yang dimaksud dengan kemampuan undak-usuk basa Sunda adalah satu kemampuan menggunakan bahasa hormat atau bahasa kasar yang disesuaikan dengan keakraban, kekuasaan dan kedudukan antara pembicara dan yang diajak bicara. Menurut Budi Rahayu Tamsyah (1996:5) undakusuk basa Sunda adalah aturan bahasa yang digunakan atau disesuaikan dalam keadaan umur, kedudukan serta situasi yang berbicara dan yang diajak bicara.

Dalam penelitian ini, alat ukur yang digunakan untuk mengukur minat dan sikap siswa adalah jenis skala Likert. Skala ini dibagi menjadi lima kategori yang disusun secara kontinum yaitu Sangat Setuju (SS), Setuju (S), Ragu-ragu (R), Tidak Setuju (TS), dan Tidak Setuju Sekali (TSS). Siswa diharapkan bisa memilih salah satu dari lima kategori tadi 
sejalan dengan pilihannya. Yang diukur dalam skala minta adalah suka atau tidaknya siswa terhadap kegiatan, subjek atau objek tertentu. Sedangkan, yang diukur dalam skala sikap adalah baik atau tidaknya sikap siswa dalam satu kegiatan tertentu. Respon atau jawaban yang dipergunakan dalam penelitian ini hanya ada empat kategori yaitu Sangat Setuju (SS), Setuju (S), Tidak Setuju (TS), dan Tidak Setuju Sekali (TSS). Untuk kategori netral atau ragu-ragu tidak dimasukkan, karena untuk menghindari jawaban siswa yang tidak jelas, sebagaimana yang dijelaskan oleh Nasution (Haerudin, 1998:23). Untuk penskoran bobot nilai tiap pernyataan dilakukan secara apriori, yaitu untuk pernyataan positif Sangat Setuju (SS) diberi bobot 4, Setuju (S) diberi bobot 3, Tidak Setuju (TS) diberi bobot 2, dan Tidak Setuju Sekali (TSS) diberi bobot 1. Sedangkan untuk pernyataan negatif yaitu Sangat Setuju (SS) diberi bobot 1, Setuju (S) diberi bobot 2, Tidak Setuju (TS) diberi bobot 3, dan Tidak Setuju Sekali (TSS) diberi bobot 4 .

Untuk mengukur hasil tes kemampuan UUBS dilakukan pengukuran menggunakan pemberian nilai;

Skor $=$ Jawaban Siswa X 2 3

\section{METODE}

Sumber data penelitian ini adalah siswa kelas X 9 SMAN 9 Bandung, yang berjumlah 39 siswa. Adapun cara yang dilakukan untuk menentukan sampel adalah dengan cara mengundi seperti arisan. Setiap kertas yang bertuliskan nama kelas X di SMAN 9 Bandung, mulai dari X-1 sampai dengan X-9 digulung serta dimasukkan ke dalam gelas atau tempat untuk mengundi, lalu diundi hingga kertas yang bertuliskan kelas X 9 keluar.

Desain penelitian yang digunakan adalah penilitian korelasional. Yang dimaksud dengan penelitian korelasional adalah menghubungkan variabel satu dengan variabel lainna, melalui model yang menggunakan sekali pengumpulan data.

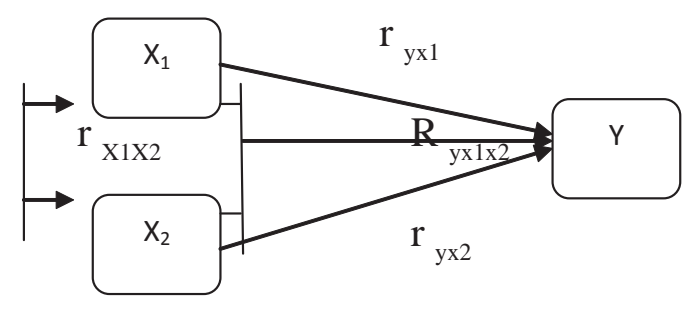

(Sugiyono, 2012: 156)

Keterangan:

$\mathrm{X}_{1}=$ Minat Belajar Siswa

$\mathrm{X}_{2}=$ Sikap Berbahasa

$\mathrm{Y}=$ Kemampuan UUBS

Metode deskriptif korelasional adalah metode yang digunakan dalam penelitian ini. Hal ini dilakukan untuk mengetahui adanya hubungan antara tiga variabel yaitu variabel minat, sikap, dan kemampuan UUBS. Data variabel minta dan sikap dikategorikan sebagai variabel bebas (independent) sedangkan variabel kemampuan UUBS dikategorikan sebagai variabel terikat (dependent). Hubungan ketiga variabel ini bisa ditampilkan dengan cara mengukur tingkat signifikansinya, sehingga bisa terlihat sebarapa besar peranan minat dan sikap terhadap kemampuan UUBS. Metode ini dipilih berdasarkan tujuan yang ingin dicapai, yaitu mendeskripsikan korelasi antara minat dan sikap terhadap kemampuan UUBS siswa kelas X 9 SMAN 9 Bandung tahun ajaran 2012/2013. Penelitian ini menggunakan analisis korelasi regresi ganda, karena di dalam penelitian ini bertujuan untuk mengetahui pengaruh dua variabel bebas terhadap variabel terikat.

Definisi oprasional dalam penelitian ini sebagai berikut: 1) minat, yang dimaksud minat dalam penelitian ini adalah minat siswa kelas X 9 SMAN 9 Bandung terhadap belajar bahasa Sunda, 2) sikap, dalam penelitian ini sikap merupakan reaksi siswa (pemakai bahasa) kelas $X 9$ SMAN 9 Bandung terhadap bahasanya sendiri dan orang lain, 3) kemampuan UUBS, adalah kemampuan siswa kelas X 9 SMAN 9 Bandung untuk mengaplikasikan penggunaan bahasa sesuai dengan aturan UUBS.

Instrumen penelitian adalah alat yang digunakan untuk penelitian. Adapun instrumen 
yang digunakan dalam penelitian ini adalah instrumen berbentuk angket dan tes.

Angket skala minat digunakan untuk mengumpulkan data atau informasi mengenai minat siswa kelas X 9 SMAN 9 Bandung terhadap belajar B. Sunda. Kisi-kisi disusun pada tabel di bawah ini.

\section{Tabel 1}

Kisi - kisi Minat

\begin{tabular}{llllll}
\hline \multirow{2}{*}{ No. } & \multirow{2}{*}{ Indikator } & \multirow{2}{*}{ Aspék } & \multicolumn{2}{c}{ Pernyataan } \\
\cline { 4 - 5 } & & & \multicolumn{2}{c}{$(+)$} & $(-)$ \\
\hline 1. & Belajar B. & $>$ & Kognitif & $1,3,4$ \\
& Sunda & $>$ & Afektif & 2 & 5 \\
\hline 2. & Penutur B. & $>$ & Kognitif & 7,8 & \\
& Sunda & $>$ & Afektif & 6 & 9,10 \\
\hline
\end{tabular}

Angket skala sikap digunakan untuk mengumpulkan data atau informasi mengenai sikap berbahasa siswa kelas X 9 SMAN 9 Bandung. Kisi-kisi disusun pada tabel di bawah ini.

Tabel 2

Kisi - kisi Sikep

\begin{tabular}{llllll}
\hline \multirow{2}{*}{ No. } & \multirow{2}{*}{ Indikator } & \multirow{2}{*}{ Aspék } & \multicolumn{2}{c}{ Pernyataan } \\
\cline { 4 - 5 } & & & $(+)$ & $(-)$ \\
\hline 1. & Bangga & $>$ & Kognitif & 1 & 2 \\
& terhadap B. & $>$ & Afektif & 3 & \\
& Sunda & $>$ & Konatitf & 4,5 & \\
\hline 2. & Belajar B. & $>$ Kognitif & 10 & \\
& Sunda & $>$ Afektif & 6 & 7 \\
& & $>$ Konatif & 8 & 9 \\
\hline 3. & Penutur B. & $>$ Kognitif & 12 & \\
& Sunda & $>$ Afektif & 11,15 & 14 \\
& & $>$ Konatif & 13 & \\
\hline
\end{tabular}

Instrumen tes digunakan untuk mengukur kemampuan siswa dalam UUBS, mencakup 15 soal. Tujuh soal menjodohkan kata, delapan soal essay merubah kalimat menjadi kalimat ragam hormat. Kisi-kisi disusun pada tabel di bawah ini.
Tabel 3

Kisi-kisi Kamampuh UUBS

\begin{tabular}{lllll}
\hline No. & $\begin{array}{c}\text { Wangun } \\
\text { UUBS }\end{array}$ & Ingetan & $\begin{array}{c}\text { Rama- } \\
\text { haman }\end{array}$ & Aplikasi \\
\cline { 3 - 5 } 1. & Basa loma & & \\
\hline 2. & $\begin{array}{l}\text { Basa } \\
\text { lemes keur } \\
\text { sorangan }\end{array}$ & $\begin{array}{l}13,14, \\
15\end{array}$ & 4,8 & $6,10,12$ \\
\hline 3. & $\begin{array}{l}\text { Basa lemes } \\
\text { keur ka } \\
\text { batur }\end{array}$ & 5 & $1,7,9$ & $2,3,11$ \\
\hline
\end{tabular}

Dalam penelitian ini penulis merumuskan hipotesis sebagai berikut:

$\mathrm{H}_{\mathrm{o}}: \mathrm{X}_{1} \mathrm{X}_{2}=\mathrm{Y}$

$\mathrm{H}_{\mathrm{a}}: \mathrm{X}_{1} \mathrm{X}_{2} \neq \mathrm{Y}$

Yang memungkinkan bisa $\mathrm{X}_{1} \mathrm{X}_{2}=\mathrm{Y}$ atau $\mathrm{X}_{1}$ $\mathrm{X}_{2} \neq \mathrm{Y}$ (Sugiono, 2012:69)

$\mathrm{H}_{\mathrm{o}}$ : tidak ada hubungan yang signifikan antara aspek minat dan sikap terhadap kemampuan UUBS

$\mathrm{H}_{\mathrm{a}}$ : adanya hubungan yang signifikan antara aspek minat dan sikap terhadap kemampuan UUBS

Penelitian ini lebih cenderung terhadap hipotesis alternatif $\left(\mathrm{H}_{\mathrm{a}}\right)$, yaitu adanya hubungan yang signifikan antara minat dan sikap terhadap kemampuan UUBS.

\section{HASIL DAN PEMBAHASAN Minat Belajar Siswa}

Data variabel minat belajar bahasa Sunda siswa dibatasi oleh 10 pernyataan. Dari 10 pernyataan ini skor terkecil adalah 10 , sedangkan skor tertinggi adalah 40 , dan nilai rata-rata idealnya adalah 25 .

Kriteria minat belajar basa Sunda siswa termasuk dalam kategori positif dan negatif dilihat dari skor rata-rata ideal 25 , artinya minat siswa dikategorikan positif jika siswa mendapat skor $\geq 25$ sedangkan siswa yang dikatagorikan negatif mendapat skor $<25$.

Bersadarkan 39 angket minat yang disebar diperoleh skor pada rentang 24 sampai 39 . Hal ini menunjukkan bahwa rata-rata siswa memiliki minat belajar bahasa Sunda. Terlihat dari 37 angket siswa yang skornya termasuk 
kategori positif, sedangkan 2 angket siswa termasuk kategori negatif.

\section{Sikap Berbahasa Siswa}

Data variabel sikap berbahasa siswa dibatasi oleh 15 pernyataan. Dari 15 pernyataan ini skor terkecil adalah 15, sedangkan skor tertinggi adalah 60, dan nilai rata-rata ideal adalah 37,5.

Kriteria sikap berbahasa siswa yang termasuk dalam kategori positif dan negatif dilihat dari skor rata-rata ideal 37,5, artinya sikap siswa dikategorikan positif jika siswa mendapat skor $\geq 37,5$ sedangkan siswa yang dikatagorikan negatif mendapat skor < 37,5.

Bersadarkan 39 angket sikap yang disebar diperoleh skor pada rentang 38 sampai 55. Hal ini menunjukkan bahwa rata-rata siswa memiliki minat belajar basa Sunda yang positif.

\section{Kemampuan UUBS}

Dalam variabel kemampuan UUBS ada 15 soal tes yang dibagika kepada siswa. Ada 2 macam jenis UUBS yang ditanyakan yaitu basa lemes keur sorangan dan basa lemes keur ka batur. Dari 15 pernyataan skor terendah yaitu 3,3 sedangkan yang tertinggi 8,7 , dan nilai ratarata idelnya adalah 7,3.

Presentase nilai kemampuan UUBS dikategorikan tinggi dan rendah. Hal ini dilihat dari nilai yang diperoleh siswa. Jika nilai siswa $\geq$ 7,3 maka kemampuan UUBS siswa dikategorikan tinggi, sedangkan kemampuan UUBS siswa dikategorikan rendah kalau nilai siswa < 7,3.

Berdasarkan 39 data siswa yang dianalisis ada beberapa siswa yang nilainya termasuk kategori rendah. Hal ini dikarenakan, kurang pahamnya siswa terhadap UUBS dan tidak biasanya siswa menggunakan UUBS.

\section{Korelasi antara Minat, Sikap, dan Kemampuan UUBS}

\section{Korelasi antara Minat terhadap Kemampuan UUBS}

Hasil perhitung menggunakan SPSS 20 nilai korelasi variabel minat belajar B. Sunda $\left(\mathrm{X}_{1}\right)$ terhadap kemampuan UUBS (Y) tampak pada tabel berikut ini:

\section{Tabel 4}

\begin{tabular}{|c|c|c|c|}
\hline \multicolumn{4}{|c|}{$\frac{\text { Korelasi antara Variabel } \mathrm{X}_{1} \text { dengan } \mathrm{Y}}{\text { Correlations }}$} \\
\hline & & Minat & Kamampuh \\
\hline & & Diajar & UUBS \\
\hline & & Siswa & \\
\hline \multirow{4}{*}{$\begin{array}{l}\text { Minat Diajar } \\
\text { Siswa }\end{array}$} & Pearson & & \\
\hline & Correlation & 1 &, 132 \\
\hline & Sig. (2-tailed) & & ,423 \\
\hline & $\mathrm{N}$ & 39 & 39 \\
\hline \multirow{3}{*}{$\begin{array}{l}\text { Kamampuh } \\
\text { UUBS }\end{array}$} & $\begin{array}{l}\text { Pearson } \\
\text { Correlation }\end{array}$ & ,132 & 1 \\
\hline & Sig. (2-tailed) & ,423 & \\
\hline & $\mathrm{N}$ & 39 & 39 \\
\hline
\end{tabular}

Berdasarkan hasil hitungan nilai korelasi yang diperoleh untuk $\mathrm{X}_{1}$ dengan $\mathrm{Y}_{\text {sebesar }}$ 0.132 berarti terdapat hubungan yang sedang antara minat belajar bahasa Sunda $\left(\mathrm{X}_{1}\right)$ dengan kemampuan UUBS (Y). Uji signifikansi untuk $\mathrm{X}_{1}$ dengan $\mathrm{Y}$ mempunyai nilai signifikansi 0.003 , yang lebih kecil dari nilai probabilitas 0.05 , maka $\mathrm{H}_{\mathrm{o}}$ ditolak dan $\mathrm{H}_{\mathrm{a}}$ diterima, yang artinya signifikan. Terbukti bahwa minat belajar bahasa Sunda mempunyai hubungan yang signifikan terhadap kemampuan UUBS.

Nilai koefisien determinasi variabel minat belajar bahasa Sunda $\left(\mathrm{X}_{1}\right)$ terhadap kemampuan UUBS (Y) tampak pada tabel berikut:

Tabel 5

Koefesien Determinasi $\mathrm{X}_{1}$ terhadap $\mathrm{Y}$

\begin{tabular}{|c|c|c|c|c|c|c|c|c|c|}
\hline \multicolumn{10}{|c|}{ Model Summary } \\
\hline \multirow[t]{2}{*}{ Model } & \multirow[t]{2}{*}{$\mathrm{R}$} & \multirow{2}{*}{$\begin{array}{c}\mathrm{R} \\
\text { Square }\end{array}$} & \multirow{2}{*}{$\begin{array}{l}\text { Adjusted R } \\
\text { Square }\end{array}$} & \multirow{2}{*}{$\begin{array}{l}\text { Std. Error } \\
\text { of the } \\
\text { Estimate }\end{array}$} & \multicolumn{5}{|c|}{ Change Statistics } \\
\hline & & & & & $\begin{array}{l}\text { R Square } \\
\text { Change }\end{array}$ & $\begin{array}{c}\mathrm{F} \\
\text { Change }\end{array}$ & df1 & $\mathrm{df} 2$ & $\begin{array}{c}\text { Sig. F } \\
\text { Change }\end{array}$ \\
\hline 1 & $.132^{\mathrm{a}}$ & .117 & .009 & 12.145 & .0117 & .657 & 1 & 37 & .423 \\
\hline
\end{tabular}


Berdasarkan tabel di atas dapat diketahui besarnya koefisien determinasi variabel minat belajar bahasa Sunda $\left(\mathrm{X}_{1}\right)$ terhadap variabel kemampuan UUBS (Y) adalah sebesar 0.117 atau $11.7 \%$. Artinya kemampuan UUBS siswa dipengaruhi oleh variabel minat belajar bahasa Sunda sebesar $11.7 \%$, sedangkan sisanya dipengaruhi oleh faktor lain.

Korelasi antara Sikap terhadap Kemampuan UUBS

Hasil perhitung menggunakan SPSS 20 nilai korelasi variabel sikap berbahasa $\left(\mathrm{X}_{2}\right)$ terhadap kemampuan UUBS (Y) tampak pada tabel 6.

Selanjutnya nilai korelasi yang diperoleh untuk $\mathrm{X}_{2}$ dengan $\mathrm{Y}$ sebesar 0.016 berarti terdapat hubungan yang sedang antara sikap berbahasa $\left(\mathrm{X}_{2}\right)$ dengan kemampuan UUBS $(\mathrm{Y})$. Uji signifikansi untuk $\mathrm{X}_{2}$ dengan $\mathrm{Y}$ mempunyai nilai signifikan 0.000 , yang lebih kecil dari nilai probabilitas 0.05 , maka $\mathrm{H}_{\mathrm{o}}$ ditolak dan $\mathrm{H}_{\mathrm{a}}$ diterima, yang artinya signifikan. Terbukti bahwa sikap berbahasa mempunyai hubungan yang signifikan terhadap kemampuan UUBS.

Nilai koefisien determinasi variabel sikap berbahasa $\left(\mathrm{X}_{2}\right)$ terhadap kemampuan UUBS (Y) tampak pada tabel 7.

Berdasarkan tabel 7 dapat diketahui besarnya koefisien determinasi variabel sikap berbahasa $\left(\mathrm{X}_{2}\right)$ terhadap variabel kemampuan UUBS (Y) adalah sebesar 0.100 atau $10 \%$. Artinya kemampuan UUBS dipengaruhi oleh sikap berbahasa sebesar $10 \%$, sedangkan sisanya dipengaruhi oleh faktor lain.

Tabel 6

Korélasi antara Variabel $X_{2}$ dengan $Y$

\begin{tabular}{|c|c|c|c|}
\hline \multicolumn{4}{|c|}{ Correlations } \\
\hline & & Sikep Makéna Basa & Kamampuh UUBS \\
\hline \multirow{3}{*}{ Sikep Makéna Basa } & Pearson Correlation & 1 & ,016 \\
\hline & Sig. (2-tailed) & & ,925 \\
\hline & $\mathrm{N}$ & 39 & 39 \\
\hline \multirow{3}{*}{ Kamampuh UUBS } & Pearson Correlation & ,106 & 1 \\
\hline & Sig. (2-tailed) & ,925 & \\
\hline & $\mathrm{N}$ & 39 & 39 \\
\hline
\end{tabular}

Tabel 7

Koefisien Determinasi Variabel $\mathrm{X}_{2}$ terhadap Variabel $\mathrm{Y}$

\begin{tabular}{|c|c|c|c|c|c|c|c|c|c|}
\hline \multicolumn{10}{|c|}{ Model Summary } \\
\hline \multirow[t]{2}{*}{ Model } & \multirow[t]{2}{*}{$\mathrm{R}$} & \multirow{2}{*}{$\begin{array}{c}\mathrm{R} \\
\text { Square }\end{array}$} & \multirow{2}{*}{$\begin{array}{c}\text { Adjusted R } \\
\text { Square }\end{array}$} & \multirow{2}{*}{$\begin{array}{l}\text { Std. Error } \\
\text { of the } \\
\text { Estimate }\end{array}$} & \multicolumn{5}{|c|}{ Change Statistics } \\
\hline & & & & & $\begin{array}{l}\text { R Square } \\
\text { Change }\end{array}$ & $\begin{array}{c}\mathrm{F} \\
\text { Change }\end{array}$ & df1 & df2 & $\begin{array}{c}\text { Sig. F } \\
\text { Change }\end{array}$ \\
\hline 1 & $.106^{\mathrm{a}}$ & .100 & -.027 & 12.251 & .000 & .009 & 1 & 37 & .925 \\
\hline
\end{tabular}

\section{Korelasi antara Minat dan Sikap Siswa terhadap Kemampuan UUBS}

Hasil perhitung menggunakan SPSS
Sunda $\left(\mathrm{X}_{1}\right)$ dan sikap berbahasa $\left(\mathrm{X}_{2}\right)$ terhadap kemampuan UUBS (Y) tampak pada tabel 8.

20 nilai korelasi variabel minat belajar $\mathrm{B}$. 
Tabel 8

Hasil Uji Signifikansi Koefisien Korelasi Ganda

\begin{tabular}{|c|c|c|c|c|}
\hline \multicolumn{5}{|c|}{ Correlations } \\
\hline & & $\begin{array}{l}\text { Minat Diajar } \\
\text { Siswa }\end{array}$ & $\begin{array}{l}\text { Sikep Makéna } \\
\text { Basa }\end{array}$ & $\begin{array}{l}\text { Kamampuh } \\
\text { UUBS }\end{array}$ \\
\hline \multirow{3}{*}{ Minat Diajar Siswa } & Pearson Correlation & 1 &, $547^{* *}$ &, 132 \\
\hline & Sig. (2-tailed) & &, 000 & ,423 \\
\hline & $\mathrm{N}$ & 39 & 39 & 39 \\
\hline \multirow{3}{*}{ Sikep Makéna Basa } & Pearson Correlation &, $547^{* *}$ & 1 &, 016 \\
\hline & Sig. (2-tailed) &, 000 & & ,925 \\
\hline & $\mathrm{N}$ & 39 & 39 & 39 \\
\hline \multirow{3}{*}{ Kamampuh UUBS } & Pearson Correlation & ,132 & ,016 & 1 \\
\hline & Sig. (2-tailed) & 423 & ,925 & \\
\hline & $\mathrm{N}$ & 39 & 39 & 39 \\
\hline
\end{tabular}

Besarnya korelasi antara variabel minat belajar B. Sunda $\left(\mathrm{X}_{1}\right)$ dan sikap berbahasa $\left(\mathrm{X}_{2}\right)$ terhadap kemampuan UUBS (Y) yang dihitung dengan koefisien korelasi adalah 0.132 dengan demikian dapat diinterprestasikan bahwa hubungan antara variabel minat belajar B. Sunda, variabel sikap berbahasa dan kemampuan UUBS sangat rendah. Tidak adanya tanda (-) di depan angka 0.132 pada tampilan output menunjukkan bahwa korelasi memiliki pola positif atau searah, sehingga dapat diinterprestasikan bahwa semakin tinggi minat belajar bahasa Sunda dan sikap berbahasa siswa, maka akan semakin tinggi pengaruhnya terhadap kemampuan UUBS.

Nilai koefisien determinasi variabel minat belajar B. Sunda $\left(\mathrm{X}_{1}\right)$ dan variabel sikap berbahasa $\left(\mathrm{X}_{2}\right)$ terhadap kemampuan UUBS (Y) tampak pada tabel berikut:

Tabel 9

Koefisien Determinasi $X_{1}$ dan $X_{2}$ terhadap $Y$ Model Summary

\begin{tabular}{|c|c|c|c|c|c|c|c|c|c|}
\hline \multirow[t]{2}{*}{ Model } & \multirow[t]{2}{*}{$\mathrm{R}$} & \multirow{2}{*}{$\begin{array}{c}\mathrm{R} \\
\text { Square }\end{array}$} & \multirow{2}{*}{$\begin{array}{l}\text { Adjusted } \\
\text { R Square }\end{array}$} & \multirow{2}{*}{$\begin{array}{l}\text { Std. Error of } \\
\text { the Estimate }\end{array}$} & \multicolumn{5}{|c|}{ Change Statistics } \\
\hline & & & & & $\begin{array}{l}\text { R Square } \\
\text { Change }\end{array}$ & $\begin{array}{c}\mathrm{F} \\
\text { Change }\end{array}$ & df1 & df2 & $\begin{array}{c}\text { Sig. F } \\
\text { Change }\end{array}$ \\
\hline 1 & $.169^{\mathrm{a}}$ & .028 & -.025 & 12.244 & .028 & .528 & 2 & 36 & .595 \\
\hline
\end{tabular}

Berdasarkan tabel di atas dapat diketahui besarnya koefisien determinasi variabel minat belajar bahasa Sunda $\left(\mathrm{X}_{1}\right)$ dan sikap berbahasa $\left(\mathrm{X}_{2}\right)$ terhadap $(\mathrm{Y})$ terhadap variabel kemampuan UUBS (Y) adalah sebesar 0.028 atau sebesar $2.8 \%$. Artinya kemampuan UUBS siswa dipengaruhi oleh variabel minat belajar bahasa Sunda $\left(\mathrm{X}_{1}\right)$ dan sikap berbahasa $\left(\mathrm{X}_{2}\right)$ sebesar $2.8 \%$, sedangkan sisanya dipengaruhi oleh faktor lain yang tidak dikaji dalam penelitian ini.
Berdasarkan uraian di atas mengenai pengujian hipotesis dapat dirangkum beberapa hal sebagai berikut:

1) Seluruh $\mathrm{H}_{\mathrm{a}}$ yang diajukan dalam penelitian ini diterima pada alpha 0.05 .

2) Berdasarkan perhitungan koefisien determinasi dapat digambarkan model determinasi variabel penelitian seperti tampak pada gambar di bawah ini: 


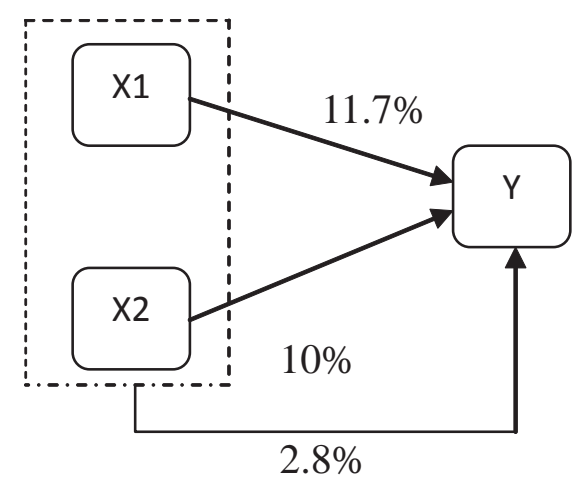

\section{SIMPULAN}

Berdasarkan analisis data yang diperoleh mengenai korelasi antara minat belajar dan sikap berbahasa terhadap kemampuan undak-usuk bahasa Sunda, maka bisa ditarik kesimpulan; berdasarkan hasil hitungan menggunakan SPSS, nilai korelasi diperoleh untuk minat belajar $\left(\mathrm{X}_{1}\right)$ terhadap kemampuan UUBS (Y) sebesar 0.132. Artinya ada hubungan yang sedang antara minat belajar dan kemampuan UUBS. Uji signifikansi 0.003 yang lebih kecil dari nilai probabilitas 0.05 , maka $\mathrm{H}_{\mathrm{o}}$ ditolak $\mathrm{H}_{\mathrm{a}}$ diterima, yang berarti signifikan. Terbukti bahwa minat belajar bahasa Sunda ada hubungan yang signifikan terhadap kemampuan UUBS; nilai korelasi yang diperoleh untuk sikap berbahasa $\left(\mathrm{X}_{2}\right)$ dengan kemampuan UUBS (Y) adalah 0.016, berarti ada hubungan yang sedang antara sikap berbahasa terhadap kemampuan UUBS. Uji signifikansi untuk $\mathrm{X}_{2}$ terhadap $\mathrm{Y}$ mempunyai nilai signifikan 0.000 , yang lebih kecil dari nilai probabilitas 0.05 , maka $\mathrm{H}_{\mathrm{o}}$ ditolak dan $\mathrm{H}_{\mathrm{a}}$ diterima, yang berarti signifikan. Terbukti bahwa sikap berbahasa mempunyai hubungan yang signifikan terhadap kemampuan UUBS; besarnya korelasi antara variabel minat belajar $\left(\mathrm{X}_{1}\right)$ dan sikap berbahasa $\left(\mathrm{X}_{2}\right)$ terhadap kemampuan UUBS (Y) yang dihitung menggunakan koefisien korelasi adalah 0.132. Oleh karena itu, bisa diinterpretasikan bahwa hubungan antara variabel minat belajar dan sikap berbahasa terhadap kemampuan UUBS rendah. Tidak ada tanda (-) di depan angka 0.132, maka menunjukkan bahwa korelasi mempunyai pola positif atau searah, jadi bisa diinterpretasikan makin besar minat belajar dan sikep berbahasa siswa maka semakin besar hasil kemampuan UUBS siswa.

\section{PUSTAKA RUJUKAN}

Departemen Pendidikan dan Kebudayaan. (1994). Kamus Besar Indonesia Edisi Kedua. Jakarta: Balai Pustaka.

Haerudin, Dingding. (1998). Peranan Sikap Berbahasa terhadap Kemampuan Menulis. Tesis IKIP Bandung: Tidak Diterbitkan.

Nurkancana, Wayan dan Sumartana. (1983). Evaluasi Pendidikan. Surabaya: Usaha Nasional.

Sugiono. (2012). Metode Penelitian Kuantitatif Kualitatif dan $R \& D$. Bandung: Alfabeta, CV.

Suwito. (1983). Sosiolinguistik. Surakarta: Henary Offset Solo

Tamsyah, Budi Rahayu. (1996). Pangajaran Sastra Sunda. Bandung: CV. Pustaka Setia.

\section{UCAPAN TERIMA KASIH}

Penulis mengucapkan terima kasih dan penghargaan kepada Prof. Dr. H. Rahman, M.Pd. dan Dr. H. Dingding Haerudin, M.Pd. sebagai pembimbing. Selain itu, juga kepada Ketua Prodi Pendidikan Bahasa dan Budaya Sunda SPs UPI, Ketua Prodi Jurusan Pendidikan Bahasa Daerah FPBS UPI, dan Kepala Sekolah SMA Rimba Madya Bogor. Terima kasih pula penulis sampaikan kepada redaksi Jurnal Lokabasa atas dimuatnya tulisan ini. 